\title{
Infographic development of Blambangan Kingdom for history learning in senior high school
}

\author{
M.N.L. Khakim*, I.Y. Afhimma, K.A. Wijaya, M.R.I. Ardiansyah, \& Marsudi \\ Universitas Negeri Malang, Malang, Indonesia
}

\begin{abstract}
Teaching materials become an essential component of learning. History learning is often considered synonymous with boring material. The purpose of this study is to develop interesting teaching materials for the historical learning. The development of teaching materials used historical research data. The Blambangan Kingdom (1293-1772) was one of the important ancient kingdoms in East Java that needed to be taught in schools. The method of this study was research and development. The steps of research and development were literature study, product design, product specification, design validation, product manufacturing, initial product testing, product revision, extensive product testing, and dissemination. Infographic teaching materials become a solution for history learning. This study develops an infographic teaching materials with a focus on the discussion about the history of Blambangan Kingdom in senior high school. This infographic is up to date because it used an attractive cartoon figure, a concise explanation, and an additional QR code to enrich the information. The implementation of infographics on 35 respondents indicates that infographic teaching materials on the history of Blambangan Kingdom are effectively used in learning supported by material points, instructions for use and evaluation questions.
\end{abstract}

Keywords: teaching materials, Infographic, Blambangan Kingdom, history learning

\section{INTRODUCTION}

Learning in the current era has progressed, especially history learning. History learning can be carried out in two approaches, namely chronologically and thematically (Sapto et al. 2019). In fact, history learning is often considered boring and dry because it only talks about facts and concepts. Of course, teachers need to gain facility related to the preparation of alternative learning in media and teaching materials to support the teaching and learning process. In optimizing the learning process, an atmosphere that can activate interaction between educators and students, students and students, and students with learning materials are needed (Rokhmah 2017). The existence of teaching materials can foster students' interest so that it creates interactive interactions and teachers have used various kinds of teaching materials in history learning. The example of those materials is textbooks, modules, handouts, worksheets, models or mock-ups, audio teaching material,s and other interactive teaching materials about Indonesia's ancient history. Researchers have also conducted research on the ancient history of Indonesia, such as ancient bathing sites in Pasuruan (Khakim et al. 2020). A study about Hindu-Buddhist buildings has also been carried out by researchers at Selokelir Temple (Khakim et al. 2020). This research is in line with previous studies on the history of ancient Indonesia for teaching history.

One of the teaching materials in the modern era is infographic teaching materials. According to Barnes in Resnatika et al. (2018), infographics are visual data that aims to provide information from

*Corresponding author: moch.nurfahrul.fis@um.ac.id 
a phenomenon where readers can interpret the infographic's meaning. The infographic teaching materials were developed because, so far, teaching materials have become an obstacle in history learning. Besides, it can visually package information so that readers can remember and understand without having to read long texts. Infographic becomes an effective alternative teaching material for history learning because the explanation of the material is in the form of points so that messages or information can be conveyed. Often, the teacher's teaching materials are not attractive, so that learning becomes boring, and learning objectives cannot be achieved. Thus, this study develops infographic teaching materials to make history learning interesting and not boring. The history of Blambangan Kingdom 1293-1772 AD in senior high school was selected as the material because this history is not attractive to be discussed. Thus, the history of the Blambangan Kingdom seems to have been eliminated from the national historiography. Therefore, it is necessary to have a historical discussion about the history of the Blambangan Kingdom 1293-1772 AD in infographic teaching materials to attract student interest in learning.

\section{METHODS}

This research used the research and development method with a model of Borg \& Gall. The procedure of research and development methods were literature study, product design, product specification, design validation, product manufacturing, initial product testing, product revision, extensive product testing, and dissemination (Setyosari 2016). The first step was a literature study to collect the information of Blambangan kingdom and identify the problem about the lack of learning material about the history of Blambangan kingdom in senior high school. The second step was the product design, carried out through designing types of teaching materials suitable for teaching the history of the Blambangan Kingdom. The third step was product manufacturing to compile the infographic about the history of the Blambangan Kingdom. The fourth step was initial product testing by the teaching materials expert. Meanwhile, in the fifth stage, the product was revised based on the review's results by the teaching material expert. The sixth step was extensive product testing to 35 students in senior high school. This step also involved a google form filled by the first grade of senior high school. In the seventh stage, the teaching material was distributed to history teachers via the internet. A quantitative approach was to analyze data based on the google form result. Thus, the last step was making a conclusion about how effective this teaching material to teach about the history of the Blambangan Kingdom for student in senior high school.

\section{RESULTS AND DISCUSSION}

\subsection{A brief history of Blambangan Kingdom}

The Blambangan Kingdom was located at the eastern tip of the island of Java, as the last Hindu kingdom in Java. Based on the source of the Balambangan inscription published by Prabu Jayanegara, Balambangan has been named a self-reliant area because it has been instrumental in suppressing the rebellion Nambi and Blambangan and were designated as a farming area (Hardiati et al. 2008). Based on the information of the Balambangan inscription, the Blambangan Kingdom had existed since the era of the Majapahit Kingdom. However, this inscription is not a marker of the establishment of the Blambangan Kingdom. Many historians even believe that the Blambangan Kingdom coincided with the fall of Singhasari and the establishment of the Majapahit Kingdom in 1293 AD (Margana 2012). When the Majapahit Empire collapsed, the Blambangan Kingdom still survived.

According to Babad Blambangan, the first King of the Blambangan Kingdom was Menak Sopal, but his reign was not explained. According to the Babad Sembar, Lembu Miruda was the first king of Blambangan and made Watu Putih Panarukan the capital of the Blambangan Kingdom. This kingdom controled most of the eastern tip of the island of Java, namely Banyuwangi, Jember, 
Lumajang, Bondowoso, and Situbondo. According to Lekkerkerker, the Blambangan was the Hindu Kingdom with a strong Hindu fortress and could not be conquered by the Mataram Sultanate.

After the collapse of Majapahit, the Demak Sultanate conquered Tuban in 1527 AD, Wirasari in 1528 AD, Surabaya in 1531 AD. Besides, Lamongan, Blitar, and Wirasaba had their turn in $1541 \mathrm{AD}$ and $1542 \mathrm{AD}$. In $1546 \mathrm{AD}$, the Demak Sultanate tried to conquer Blambangan but failed despite its success in expanding hegemony to Hindu areas in the interior of Java (Anshori \& Dri Arbaningsih 2008).

For almost three centuries, the Blambangan Kingdom was under the influence of Mataram and Bali's supremacy struggle. The kingdom of Mengwi, Bali was then more successful in exerting influence in Blambangan. Bali's kings used the Blambangan Kingdom to fight the expansion of the Mataram Sultanate (Margana 2012). The Balinese Kingdoms did this because they were afraid that Islam could penetrate Bali and change Bali's cultural structure. Therefore, Blambangan Kingdom was used as the last stronghold of Hinduism in Java so that Islam did not spread to the island of Bali. Blambangan had important trading centers (Veenman et al. 1927). It was clear that the VOC's main interest in Blambangan was to impose a trade monopoly by the VOC on the territory of the Blambangan Kingdom.

Blambangan fighters staged a counterattack against the VOC. The attacks were aimed at the VOC strongholds, carried out simultaneously and completely. The VOC troops were defeated by the Blambangan fighters. Lieutenant Kornet Tinne and countless VOC soldiers were killed. The remaining VOC soldiers withdrew to Kuta Lateng, then retreated to Ulu Pangpang (Ali 2002). The Blambangan fighters won a brilliant victory. Early in $1772 \mathrm{AD}$, the VOC mobilized the East Java coastal regents to attack Blambangan. They decided to burn down the village that had the food supplies for the Blambangan warriors in Bayu. On April 20, 1772 AD, about 200 Madurese soldiers led by Alap-Alap and 112 Javanese soldiers from Besuki led by Captain Wayan Buyung attacked the Blambangan fighters. The VOC sent a further military expedition to conquer Bayu. On May $16,1772 \mathrm{AD}$ VOC troops and their allies attacked Bayu and were again defeated by Blambangan fighters (Utojo 2015).

The VOC sent a further military expedition to conquer Bayu. On June 11, 1772 AD, there was another battle between the VOC and Blambangan. In this battle, the leader of the resistance, Rempeg Jogopati died (Margana 2012). Although the resistance leader died, the founders of Bayu decided to wage a Puputan war, an all-out war against the VOC. VOC prepared the final blow to break the resistance of the Blambangan fighters in Bayu. The VOC was sure that with the killing of Rempeg Jogopati the Blambangan fighters would not stem the attack. After this incident, the condition of the Blambangan Kingdom, which was completely destroyed, stopped the struggle to continue. After October 11, 1772 AD, the Puputan War launched by the Blambangan Kingdom ended.

\subsection{Implementation of the infographic for history learning}

The study of history has a wide range of material, one of which is the Hindu-Buddhist kingdom's material. The material was derived from competency standards, namely analyzing the journey of the Indonesian nation during the traditional countries, then becoming basic competencies (KD) 3.6. The material on the Hindu-Buddhist kingdom in Indonesia is taught in senior high school in relation to this. Based on this material, there are teaching materials that support the learning activities. Infographic teaching materials are one of the visual teaching materials that provide a concept in simplifying information or learning materials in the form of images, maps, and graphics to make it easier for readers. These teaching materials are arranged systematically according to the basic competencies of history learning, especially on Hindu-Buddhist main subjects. HinduBuddhist infographic teaching materials were implemented at senior high school students in grade $\mathrm{X}$ semester 1. Hindu-Budha's main material is focused on the presentation and analysis of material on the history of the Blambangan Kingdom (1293-1772).

The preparation of this infographic teaching materials also considered the effectiveness and innovation in the application of learning so that the material presented reaches the students. Infographic 
Table 1. Infographic teaching materials on the history of Blambangan Kingdom 1293-1772 AD.

Design infographic

The preparation of infographic teaching materials with the presentation of material on the history of Blambangan Kingdom 1293-1772 AD based on essential points supported by instructions for use and evaluation questions accompanied by a barcode containing material that has been compiled briefly and densely with references.

- Page 1: Brief explanation of the material

- Page 2: Instructions for using infographic teaching materials

1. The teacher provides directions for students to prepare cell phones.

2. The teacher provides a brief explanation as an overview of the material.

3. The teacher shows the infographic teaching materials to the students.

4. Teachers form groups/individuals to analyze the points presented in the infographic teaching material.

5. The teacher provides a barcode containing material on the Hindu-Buddhist history of the Blambangan Kingdom 1293-1772 AD.

6. The teacher provides the opportunity for students to ask questions and answer questions.

- Page 3: Evaluation questions
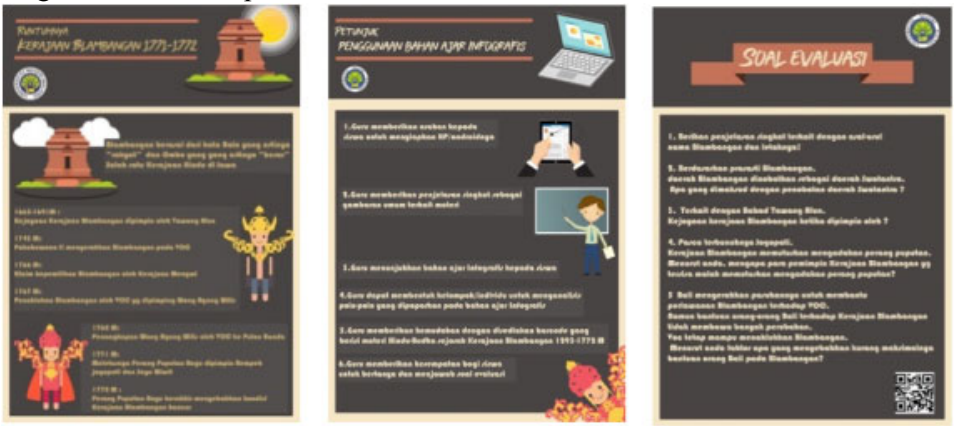

teaching materials have the advantage of explaining material from complex to simple and practical to use. In that sense, it is in the form of points that cover the entirety so that it is easy to understand and adjusts the learning needs of students to suit learning objectives. The existence of this infographic teaching materials and the evaluation of the question are expected to support students' learning interest and understanding in addition to books and explanations from the teacher. The implementation of the material on the history of Blambangan Kingdom 1293-1772 AD by combining infographic teaching materials can properly become qualified teaching materials and support student learning outcomes through visualization of infographics (Table 1).

After the presentation of the statement of the infographic teaching materials on the history of the Blambangan Kingdom presented in Table 1, data research on the effectiveness of the teaching material was collected. In this case, 35 respondents filled out a questionnaire on the google form. The research results are presented in percentage form in the Table 2.

Based on the questionnaire data, most of the responses to questions numbered one to four are "Effective" in assessing infographic teaching materials with the history of the Blambangan Kingdom 1293-1772 AD material. Respondents were presented with four questions related to the effectiveness of infographic teaching materials as supporting learning history. The results obtained from the research data show that an average of $40 \%$ of each question item refers to an effective result. The respondents also suggested various criticisms and suggestions, such as image addition, changing fonts, choosing colors, and arranging to be more innovative. Therefore, infographic teaching materials can be classified as effective teaching materials used in learning based on data from 35 respondents, which are equipped with instructions for use and evaluation questions to support students' cognitive aspects. 
Table 2. Data on the results of research on the effectiveness of infographic teaching materials.

\begin{tabular}{|c|c|c|c|c|c|c|}
\hline \multirow[t]{2}{*}{ No. } & \multirow{2}{*}{$\begin{array}{l}\text { Question } \\
\text { indicator }\end{array}$} & \multicolumn{5}{|c|}{ Descriptions of the Effectiveness Scale } \\
\hline & & Ineffective & Less effective & Effective enough & Effective & Excellent \\
\hline 1. & $\mathrm{~A}$ & $0,0 \%$ & $2,9 \%$ & $37,1 \%$ & $40 \%$ & $20 \%$ \\
\hline 2. & $\mathrm{~B}$ & $2,9 \%$ & $11,4 \%$ & $28,6 \%$ & $40 \%$ & $17,1 \%$ \\
\hline 3 . & $\mathrm{C}$ & $0,0 \%$ & $0,0 \%$ & $25,7 \%$ & $42,9 \%$ & $31,4 \%$ \\
\hline 4. & $\mathrm{D}$ & $0,0 \%$ & $0,0 \%$ & $34,3 \%$ & $42,9 \%$ & $22,9 \%$ \\
\hline
\end{tabular}

Description from question indicator

A How effective the infographic teaching materials in presenting the history of the Blambangan Kingdom?

B How effective the infographic teaching materials in the history of Blambangan Kingdom 1293-1772 AD material used for the independent learning process?

C How effective the infographic teaching material in the history of Blambangan Kingdom 1293-1772 AD material used for the learning process accompanied by teachers?

D How effective the Infographic teaching material in the history of Blambangan Kingdom 1293-1772 AD in increasing your knowledge of Hindu-Buddhist material?

\subsection{Infographic teaching material development}

The existence of teaching materials eases the educational aspect. According to the National Center for Competency Based Training (Prastowo 2015), teaching materials are all materials used to assist teachers in carrying out the learning process. Teaching materials are all materials that are systematically arranged to show all the competencies used in the learning process to achieve learning objectives. Teaching materials contain the entire learning technique designed by the teacher and implemented in the learning process. Teaching materials are made based on curriculum needs and student conditions and must be according to the times (Krismawati et al. 2018).

In the reality of education, there are still many educators who use conventional teaching materials; however, it is not enough that the current teaching materials must be compiled in an attractive, effective, and efficient manner by developing their innovations. Teaching materials must be arranged in an attractive manner so that students have more interest in historical learning material. One of the distributions of teaching materials according to their form (visual) is printed teaching materials. Printed teaching materials are teaching materials in the form of paper that function as learning needs and convey information and examples of printed teaching materials, one of which is an infographic (Prastowo 2015).

Infographic stands for Information and Graphics. Infographics are part of the science that supports business and commerce, which are presented in the form of visual information and contain more text and image data to be more attractive. The design of teaching materials with graphic elements has a higher value (Aldila 2019). Infographics use visual elements such as images, charts, maps, and charts so that the message on the infographic can be conveyed systematically and easily understood by readers. The visual form of the infographic is designed as attractive as possible so that the teaching materials used by teachers and students are not boring. Infographics have the benefit of conveying information clearly and effectively (Yahya et al. 2017).

Students are one of the audiences who experience limited time in utilizing various written historical sources. Infographics are a solution for students who want to dig as deep as possible knowledge with limited time and go hand in hand with a visual learning style. It can be in the form of diagrams or maps that will make it easier for students because the human brain will more easily understand the learning material presented (Sari 2017). The delivery of material equipped with visual illustrations can provide a stimulus for the brain to imagine history. With the existence of imagination, history learning becomes fun and as if students experience historical events themselves. This is because historical imagery will make history learning livelier and more enjoyable. The imaginative side of history that is raised will make students construct a historical event (Subakti 2010). 
The advantages of infographic teaching materials are that it exposes complex data to simple. The messages presented in an image are faster to understand, arouses imagination, is an objective source of information, and explains events coherently. Correct understanding of the learning messages conveyed is a necessity for the teacher to achieve learning objectives. In making infographics, certain design principles must be considered, such as simplicity, coherence, emphasis, and balance. Visual elements that need to be considered are shapes, lines, space, texture, and color (Sari 2017). The visualization generated from the infographic is an integral part of conveying information so that it is easy and fast to understand. The novelty of this infographic is it used the attractive cartoon figure and additional QR code. The steps for using this infographic-based teaching material are, first, the teacher introduces the importance of studying the history of the Blambangan kingdom in East Java. Second, the teacher displays this infographic on the History of the Blambangan Kingdom. Third, students read and understand the history teaching materials of the Blambangan Kingdom. Fifth, students scan the QR code on the infographic to explore information about the Blambangan Kingdom. Fourth, students work on evaluation questions under the guidance of the teacher. Finally, students and teachers discuss the answers to the evaluation questions and conclude the history lesson of the Blambangan Kingdom.

\section{CONCLUSION}

Teaching materials are all materials arranged systematically, according to student needs, basic competencies, and learning objectives. Infographic teaching materials are teaching materials based on visual graphic design. The Blambangan Kingdom (1293-1772) was founded almost simultaneously with the Majapahit Kingdom's establishment. The Blambangan Kingdom lost to the VOC expeditionary force, so that it had to be destroyed. The material on the history of the Blambangan Kingdom is suitable to be taught with infographic teaching materials. This study examines the uses of infographic teaching materials on the historical material of the Blambangan Kingdom in senior high school. Based on data from 35 respondents, the infographic teaching materials are effective to be used in learning supported by material points, instructions for use, and evaluation questions. This infographic's novelty is it used an attractive cartoon figure, the information is easy to understand, and an additional QR code.

\section{REFERENCES}

Aldila, T. H., Akhmad Arif Musadad, \& Susanto. (2019). Infografis Sebagai Media Alternatif Dalam Pembelajaran Sejarah Bagi Siswa SMA. Andharupa: Jurnal Desain Komunikasi Visual \& Multimedia Vol. 05 No. $01,4$.

Ali, H. (2002). Sekilas Perang Puputan Bayu Sebagai Tonggak Sejarah Hari Jadi Banyuwangi Tanggal 18 Desember 1771. Banyuwangi: Pemerintah Kabupaten Banyuwangi.

Anshori, N., \& Dri Arbaningsih. (2008). Negara Maritim Nusantara Jejak Sejarah Yang Terhapus. Sleman: Tiara Wacana.

Babad Tawang Alun. (n.d.). 2-5.

BudiSantoso. (2006). Sriwijaya Kerajaan Maritim Terbesar Pertama di Nusantara. Jurnal Ketahanan Nasional, $X I(1), 5$.

Hamid, A. R. (2013). Sejarah Maritim Indonesia. Yogyakarta: Penerbit Ombak.

Hardiati, E. S., Djafar, H., Soesoro, \& Ferdinandus, P. \&. (2008). Sejarah Nasional Indonesia II: Zaman Kuno. Jakarta: Balai Pustaka.

Krismawati, N. U., Warto, \& Suryani, N. (2018). Analisis Kebutuhan pada Bahan Ajar Penelitian dan Penulisan Sejarah di Sekolah Menengah Atas (SMA). Briliant: Jurnal Riset dan Konseptual Volume 3 Nomer 3.

Kuntowijoyo. (2013). Pengantar Ilmu Sejarah. Sleman: Tiara Wacana.

Margana, S. (2007). The Struggle for Hegemoni of Blambangan. Leiden: Universiteit Leiden.

Margana, S. (2012). Perebutan Hegemoni Blambangan. Yogyakarta: Pustaka Ifada.

Marihandono, D., \& Harto Juwono. (2008). Sultan Hamengkubuwono II Pembela Tradisi dan Kekuasaan Jawa. Yogyakarta: Banjar Aji Production. 
Muljana, S. (2008). Sriwijaya. Bantul: LKiS Pelangi Aksara Yogyakarta.

Nurmaria. (2017). Gerakan Sosial Politik Masyarakat Blambangan Terhadap Kompeni di Blambangan Tahun 1767-1768. Patanjala Vol. 9 No. 2, 3.

Poesponegoro, M. D., Nugroho Notosusanto, R.P. Soejono, \& R.Z. Leirissa. (2010). Sejarah Nasional Indonesia Volume 2. Jakarta: Balai Pustaka.

Prastowo, A. (2015). Panduan Kreatif Membuat Bahan Ajar Inovatif. Jogjakarta: Diva Press. Cetakan viii.

Resnatika, A., Sukaesih, \& Kurniasih, N. (2018). Peran Infografis sebagai Media Promosi dalam Pemanfaatan Perpustakaan. Jurnal Kajian Informasi \& Perpustakaan Vol.6 No.2.

Rokhmah, F. N. (2017). Pengembangan Bahan Ajar Sejarah Kebudayaan Islam "Masa Rasulullah Periode Mekah" berbasis Accelerated Learning. Tesis. Progam Studi Pendidikan Agama Islam Pascasarjana Institut Agama Islam Negeri Purwokerto.

S., H. B. (2006). Sriwijaya Kerajaan Maritim Terbesar Pertama di Nusantara. Jurnal Ketahanan Nasioal, (XI) 1,5 .

Sapto, A., Lutfiyah, A., Ridhoi, R., \& Khakim, M. N. (2019). Pengembangan Kajian Sejarah Tematik Sebagai Alternatif Bahan Ajar Sejarah Tingkat Menengah Atas di Blitar. Jurnal Praksis dan Dedikasi Sosial Vol. 2 No.1.

Sari, E. P. (2017). Pengembangan Media Berbentuk Infografis Sebagai Penunjang Pembelajaran Fisika SMA Kelas $X$. Lampung: FTK Universitas Islam Negeri Raden Intan (Skripsi).

Sholeh, K. (2017). Jalur Pelayaran dan Perdagangan Sriwijaya Pada Abad ke-7 Masehi. Siddhayatra Vol. 22, 2.

Sholeh, K. (2019). Pelayaran Perdagangan Sriwijaya dan Hubungannya Dengan Negeri-Negeri. Jurnal Historia Volume 7, Nomor 1, 2.

Subakti. (2010). Paradigma Pembelajaran Sejarah Berbasis Konstruktivisme. Paradigma Pembelajaran Sejarah. ....(Y.R. Subakti) SPPS, Vol. 24, No. 1, 3.

Sudjana, I. M. (2001). Nagari Tawon Madu: Sejarah Politik Blambangan abad XVIII. Bali: Larasan Sejarah.

Sundoro, H. M. (2008). Pangeran Rempeg Jagapati: Pahlawan Perjuangan Kemerdekaan di Tanah Blambangan. Banyuwangi: Dinas Kebudayaan dan Pariwisata Kabupaten Banyuwangi.

Suparman, H. (1987). Bahasa Osing di Kabupaten Banyuwangi. Jakarta: Universitas Indonesia.

Utojo, S. (2015). Kumpulan Catatan Sejarah Kabupaten Banyuwangi. Banyuwangi: Yayasan Puri Gumuk Merang.

Veenman, H., Zonen, \& Wageningen. (1927). Balambangansch Adatrecht. Banyuwangi: Pusat Study Budaya Banyuwangi.

Wahyudi, B. S. (2013). Pengembangan Bahan Ajar Berbasis Model Problem based Learning Pada Pokok Bahasan Pencemaran Lingkungan Untuk Meningkatkan Hasil Belajar Siswa Kelas X Sma Negeri Grujugan Bondowoso. Jember: FKIP Unej.

Yahya, S., Wibawa, M., \& Surya, A. (2017). Infografis Kompetensi Multimedia dan Desain Grafis di Provinsi Jawa Timur. Journal of Art, Desaign, Art Education and Culture Studies (JADECS) Vol. 2 No. 2 (journal2.um.ac.id).

Yuliati. (2014). Kejayaan Indonesia Sebagai Negara Maritim (Jalesveva Jayamahe). Jurnal Pendidikan Pancasila dan Kewarganegaraan, Th. 27, Nomor 2, 6. 